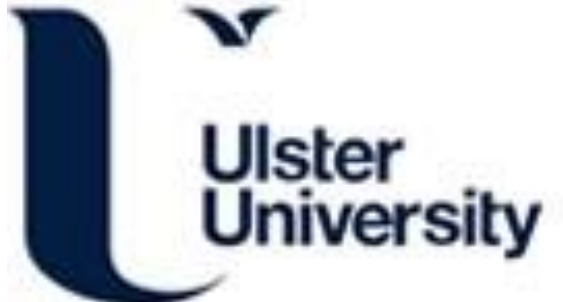

\section{Lessons from Transitional Justice? Toward a New Framing of a Victim-Centered Approach in the Case of Historical Institutional Abuse}

Hamber, B., \& Lundy, P. (2020). Lessons from Transitional Justice? Toward a New Framing of a Victim-

Centered Approach in the Case of Historical Institutional Abuse. Victims \& Offenders: An International Journal of Evidence-based Research, Policy, and Practice, 15(6), 744-770.

https://doi.org/10.1080/15564886.2020.1743803

Link to publication record in Ulster University Research Portal

Published in:

Victims \& Offenders: An International Journal of Evidence-based Research, Policy, and Practice

Publication Status:

Published online: 15/04/2020

DOI:

10.1080/15564886.2020.1743803

\section{Document Version}

Author Accepted version

\section{General rights}

Copyright for the publications made accessible via Ulster University's Research Portal is retained by the author(s) and / or other copyright owners and it is a condition of accessing these publications that users recognise and abide by the legal requirements associated with these rights.

\section{Take down policy}

The Research Portal is Ulster University's institutional repository that provides access to Ulster's research outputs. Every effort has been made to ensure that content in the Research Portal does not infringe any person's rights, or applicable UK laws. If you discover content in the Research Portal that you believe breaches copyright or violates any law, please contact pure-support@ulster.ac.uk. 


\title{
Lessons from Transitional Justice? Towards a new framing of a victim- centred approach in the case of historical institutional abuse
}

\author{
Brandon Hamber and Patricia Lundy ${ }^{1}$ \\ Ulster University
}

This article has been accepted (13 March 2020) for publication in Victims \& Offenders: An International Journal of Evidence-based Research, Policy, and Practice published by Taylor \& Francis

\begin{abstract}
The article critically examines transitional justice mechanisms to determine if historical abuse inquiries can learn from this field of practice. The article explores the Northern Ireland Historical Institutional Abuse Inquiry which reported its findings in January 2017 as a vehicle for addressing what lessons might be learned or shared between the fields of transitional justice and investigations into historical abuse. Through detailed analysis of empirical research with those that gave testimony to the Inquiry, including fourthly-three victims and Inquiry transcripts, the article explores to what extent the Inquiry was victim-centred, enabled victim participation (beyond giving testimony) and addressed victim needs. The article shows that many of the flaws of transitional justice mechanisms have been replicated when dealing with historical child abuse. Drawing on lessons from transitional justice - both positive and negative - the article outlines five broad areas for consideration that could strengthen the victim-centred nature of approaches to dealing with the legacy of historical child abuse. The article concludes that addressing victims' needs should be at the centre and drive approaches and processes for both transitional justice and historical institutional abuse.
\end{abstract}

\section{Keywords}

historical institutional abuse, child abuse, transitional justice, inquiries, justice, Northern Ireland, victims, victim participation, needs, human rights violations

\footnotetext{
${ }^{1}$ Brandon Hamber is the John Hume and Thomas P. O'Neill Chair in Peace based at the International Conflict Research Institute (INCORE) and the Transitional Justice Institute (TJI), Ulster University, Northern Ireland. Patricia Lundy is Professor of Sociology, School of Applied Social and Policy Sciences, Ulster University, Northern Ireland. All correspondence to Brandon Hamber at Ulster University, Magee Campus, Room MD142, Northland Road, Derry/Londonderry, BT48 7JL, Northern Ireland, b.hamber@ulster.ac.uk, $+44(0) 2871675500$.
} 


\section{Introduction}

The legacy of historical institutional abuse (HIA) by a range of institutions, and the Catholic Church specifically, has reverberated across the globe over the last two decades. The issue of HIAs has garnered significant political attention in at least twenty countries leading to numerous inquiries and investigations (Sköld, 2016; Swain, Wright, \& Sköld, 2018). There is a growing scholarship on the topic focusing on as diverse cases as The Royal Commission into Institutional Responses to Child Sexual Abuse in Australia (Wright \& Swain, 2018); and multiple inquiries in the USA (Terry, 2015); the Republic of Ireland (Brennan, 2015; Gallen, 2016); Denmark and Sweden (Sköld, 2016); as well as England, Scotland and Wales (Corby, Doig, \& Roberts, 2001; Duncalf, Hawthorn, Davidson, Goddard, \& McMahon, 2009) and Northern Ireland (Lundy, 2020; Lundy \& Mahoney, 2018). The crisis has not been reported to the same extent in Africa, Asia, and South America (Terry, 2015), but cases are emerging (Glatz, 2013).

Victims $^{2}$ of historical institutional child abuse have several routes in pursuit of justice, through criminal prosecution, civil litigation, public inquiries and redress schemes. A common response to HIA, certainly in the European context, has been to launch an inquiry investigating the past, with most of these inquiries built around interviews, oral history or narrative testimony most typically leading to apology, compensation and redress (Daly, 2014; Sköld, 2016; Swain et al., 2018).

In examining the scholarship in the area of HIA, what is interesting, is how, in a relatively short time, a new area of study has emerged. This has included research into HIA and trends worldwide (Wright, Swain, \& Sköld, 2017); concerns with the legal parameters

\footnotetext{
${ }^{2}$ The term victim is used in this article as it is the recognised legal term for those who have suffered violations in the past at the hands of others, and most recognisable by the wider public. That said, it is acknowledged that using the term victims can suggest limited agency or resilience, albeit not the intention of the authors. The use of the term victim by the authors does not preclude self-identification to other categorisations such as survivor or none.
} 
and scope of inquiries (Law Commission of Canada, 2000; Skold \& Swain, 2015; Wright, Sköld, \& Swain, 2018); issues of justice for victims (Daly, 2014; Gallen \& Gleeson, 2018); procedural and restorative justice (McAlinden \& Naylor, 2016), and whether victims themselves have benefitted from the processes (Golding, 2018; Lundy, 2020; Lundy \& Mahoney, 2018; Swain et al., 2018;). Throughout this scholarship limited reference is made to transitional justice $(\mathrm{TJ})$.

In Ireland, for example, the Ryan Commission established in 2000, which uncovered decades of endemic abuse in institutions in the Republic of Ireland (CICA, 2009), has been likened to "a form of truth commission" and also said to be inspired by the South African Truth and Reconciliation Commission (McAlinden, 2013, p.2). The National Inquiry into the Separation of Aboriginal and Torres Strait Islander Children from Their Families (the 'Stolen Generations Inquiry') has been considered by some as a truth commission (Henry, 2015). At a government level, the Irish Minister for Children and Youth Affairs, Catherine Zappone, has explored the use TJ as a way of dealing with the scandal of Mother and Baby Homes operated by the Catholic Church in Ireland and linked to mass graves of infants (Loughlin, 2017; Irish Government News Service, 2017). The United Nations Committee on the Rights of the Child has also acknowledged the potential of transitional justice to evaluate the Catholic Church's response to systemic abuse globally (UN, 2014). It has also been argued that inquiries into HIA have at very least been "mimicking some of the forms of $\mathrm{TJ}$ " and "manifested much of the substance" of TJ (using trials, inquiries and offering reparations) (McAuliffe, 2017, p.455 and 473).

However, only a handful of scholars have begun to explore the relationship between TJ and HIA in more depth (Gallen, 2016; Henry, 2015; King, 2018; McAlinden, 2013; McAuliffe, 2017; Nagy, 2013; Sköld, 2016). Developing this growing focus on transitional justice is the main orientation of this article, which is not to say that other approaches to HIA, beyond the 
present scope, might also offer enhanced victim participation (see for example work on restorative justice, e.g. Gavrielides, 2012; McAlinden \& Naylor, 2016). The specific focus is therefore on victims and to what extent TJ and HIA processes are victim-centred, enabled victim participation (beyond giving testimony) and addressed their needs, rather than the mechanics of legal or institutional reform. The article explores these issues next and then briefly outlines how TJ has addressed victims needs to date. After that, the article focuses on the Northern Ireland Historical Institutional Abuse Inquiry (HIAI), highlighting, based on empirical research, ${ }^{3}$ some of the current challenges with regards to the treatment of victims. By drawing on the case study and the wider literature, the article then concludes by making a set of recommendations on how a victim-centred framing of dealing with HIA, that is informed by lessons from TJ, can be advanced.

\section{Transitional Justice and Historical Institutional Abuse}

James Gallen has argued that although TJ has focused on post-conflict or post-authoritarian societies exclusively, the issue of clerical child sexual abuse could fit, at least to a degree, within the attempts to do justice for past abuses through TJ's harm-centric approach aimed at restoring basic norms (Gallen, 2016). Likewise, McAuliffe argues TJ can provide "normative guidance on the constituent elements of a sensitive response to patterns of harm" (McAuliffe, 2017, p.453). In the Australian case, it is argued that a TJ framework could better serve historical injustices against aboriginal people as it enables a normative evaluation of the nature and extent of justice measures (Henry, 2015). Others too have argued that using a TJ lens to consider the legacy of abuse in the Catholic Church can help frame accountability (King, 2018).

\footnotetext{
${ }^{3}$ Professor Lundy wishes to acknowledge and thank the Leverhulme Trust for a Major Research Fellowship Grant (MRF-2015-124) which enabled the empirical research to be conducted.
} 
A common feature of inquiries since the 1990s is a focus on victim testimony, victims' voice and storytelling (Lundy, 2020; McAlinden, 2013; McAlinden \& Naylor, 2016; Wright et al., 2018), which also intersects with much TJ thinking. Reflecting on the various commissions in Ireland, it has been observed that they lean heavily on and share the language of accountability with TJ while using the metaphors of "healing, restoration of lost balances, and closure" (McAuliffe, 2017, p.454). In other words, the language and tools of TJ are being mainstreamed into the response to institutional child abuse (McAlinden, 2013).

At the same time, inquiries focusing on HIA have been criticised for being overly concerned with attributing fault for individual acts or omissions obscuring institutionalised policies and practices (McAlinden, 2013). The extensive Ryan Report (2600 pages built on the testimony of 1500 witnesses) was criticised for failing to fully outline how deep the state was connected with HIA and the Churches in Ireland (Arnold, 2009). Comprehensive academic investigations into historical abuse (O'Sullivan and O'Donnell, 2007, 2012) have filled gaps in some areas, and certainly documented the more longitudinal changes in different institutions, however, due to their unofficial nature they have not permeated public consciousness. Gallen (2016) therefore concludes that despite the numerous inquiries specifically focusing on HIA by the Catholic Church, and thousands of cases and abuses uncovered through various sources, the wider picture is still not fully known, and issues such as state knowledge or involvement are underexplored. To this end, it is hoped a more TJdriven focus on HIA would be useful in providing a socio-political analysis of violations and painting an "overall picture of the nature, culture and context of violations" (Gallen, 2016, p.345). The wider focus of a TJ approach could also highlight, according to Gallen (2016), ongoing systemic social injustices.

Finally, it is argued that TJ offers a more victim-centric focus than current HIA process. King analyses many of the steps taken by the Catholic Church to deal with sexual 
abuse and argues that although they have some elements of TJ (such as prosecutions, internal processes of punishment such as defrocking, compensation), on the whole have failed victims and they are still "left out of the conversation" (King, 2018, p.123). In terms of accountability, the Ryan Report, for example, is seen as a "flawed document" in terms of truth-telling, mainly because potential abusers were offered anonymity leaving some victims dissatisfied (McAuliffe, 2017, p.464). Given these problems with HIA inquiries to date, Gallen argues that a victim-centred approach exists more strongly in TJ discourse and practice, and hence, it would make a better framing for the debate moving forward (Gallen, 2016). Irish Minister for Children and Youth Affairs, Katherine Zappone, echoed this view when she noted: "transitional justice puts survivors and victims at the heart of the process" (Boston College University Communications, 2018).

However, the question is: can TJ concepts and practice fill these gaps? It is the contention of the current article that, although a TJ framework can bring much to the debate analytically about HIA (reframing toward a focus on systemic questions), learning lessons from the victim-centered approach of TJ presents a more formidable challenge. The latter in particular is a key focus of this article.

\section{Transitional Justice and Victims}

\section{The growth of the victim-centred approach}

When it comes to TJ there is little doubt that victim-centred discourse has grown exponentially. The importance of victim participation internationally is increasingly recognised (Ferstman, 2010) and is deeply entrenched in policy (Bonacker, Form, \& Pfeiffer, 2011). This has resulted in victims moving from being passive to more active in TJ (de Waardt \& Weber, 2019) and victims are now the "lifeblood" of most TJ process (Former ICTY tribunal judge cited in Stover, 2004). The United Nations, through its policy on TJ, 
notes that it is essential to "ensure the centrality of victims in the design and implementation of TJ processes and mechanisms" (UN, 2010, p.2 and p.4). Victim participation is now unequivocally an "an axiom” of TJ (Sprenkels, 2017), even if what victim-centred or indeed participation involves remains unclear.

Victims participation has many benefits including, among others, empowerment and overcoming powerlessness, increasing trauma healing, decreasing isolation and marginalisation, allowing for community acceptance and reintegration, and can make victims feel valued, dignified and recognised as rights-holders (Redress, 2012; Sprenkels, 2017; Taylor, 2014). Victim participation is also said to contribute to the broader impact of any TJ process making them more locally informed, increasing trust, encouraging victims to come forward and helping to identify victims' needs (Sprenkels, 2017 3658; Taylor, 2014). Victim participation can increase the likelihood of non-repetition as victims can play a role in institutional changes (Correa, Guillerot, \& Magarrell, 2009).

However, despite some successes, most scholarship is critical of the treatment of victims in TJ. Notwithstanding a general universal commitment to the principle of victimcentredness, in practice, full participation is often superficial (de Waardt \& Weber, 2019). Victims are primarily still seen as "objects" in TJ with little power to influence outcomes (Robins, 2017). A cross-country study of victim participation in TJ mechanisms in Guatemala, Cambodia, Tunisia, Burundi, Honduras and Kenya showed the reality lagged behind the "mantra" of victim participation (Sprenkels, 2017). Victim participation in TJ therefore remains an aspiration rather than a reality.

\section{Victim voice and participation}

When it comes to truth commissions, the idea of victim voice and participation is prominent, certainly in terms of many truth commissions overall stated purpose. There has been 
substantial research on the South African Truth and Reconciliation (TRC) process, and it has found that perceptions of fairness of the TRC and its amnesty provisions among the public increased if they felt that victims had "voice" in the process (Gibson, 2002); and that it was proceduarlly fair if they had time to tell their story (Phakathi \& van der Merwe, 2007). Many victims valued the space to recount their suffering (Hamber, 2009). At the same time, in the South African TRC amnesty process, victim participation was minimal and seldom were survivors' needs, views and concerns adequately considered (Sarkin, 2007).

A further constraint was the TRC's focus was on actions violating the "bodily integrity" of an individual (Mamdani, 2015) and the restricted focus on civil-political rights (Gready \& Robins, 2014), rather than wider socio-economic, systemic and structural violence. The result was that violence was cast within the framework of individual criminal culpability (Mamdani, 2015). This overly individual and legal focus shared by many TJ processes means that wider social needs of victims beyond prosecution and truth-telling are sidelined (Robins, 2017). The result is that the deep continuities in social inequality, structural violence, gender inequalities and foreign involvement in local violence can be obscured (Nagy, 2013) despite victim participation in TJ mechanisms. For example, the direct violence focus of the TRC meant most women spoke of direct violations against men (their husbands and sons) rather than sharing their own wider stories of individual and structural suffering (Goldblatt \& Meintjies, 1997; Hamber, 2009; Ross, 2003; Wilson, 2001). Other issues impact on participation in TJ processes and on individuals after participation. In some cases, victims feared persecution from perpetrators still in power (Sprenkels, 2017). Stigma, loss of status and isolation following involvement in TJ processes has been documented in Nepal (Robins, 2011) and Rwanda (Brounéus, 2008). Security problems, ongoing discrimination, intimidation, harassment and threats at a local level is found in a range of countries (Brounéus, 2008; Sprenkels, 2017). A review of several 
international case examples concluded that on the whole victims find it hard to influence TJ processes, and obtain benefits from them (Sprenkels, 2017). For participation to be credible, victims should be centrally involved in the initiation, design, implementation, monitoring, evaluation and follow-up of processes and mechanism in which they participate (Sprenkels, 2017; United Nations OHCHR, 2009), as well as be resourced in order to effectively influence mechanisms that increase their well-being and meet their needs.

\section{Localising experiences and instrumentalising victims}

The state-centric approach to TJ is increasingly questioned, and the emphasis on TJ from below has emerged challenging narrow assumptions about how victim needs, and participation are best addressed (Clark 2010; Lundy \& McGovern, 2008; McEvoy \& McGregor, 2010; Sharp, 2015). So-called hybrid or mixed approaches have now emerged as the dominant approach to TJ. A combination of trials (to prosecute those most responsible), truth commissions (to uncover a fuller truth about the past), along with so-called traditionbased approaches or community-based rituals have become the preferred way to think of TJ (Hamber, 2015). Victim participation advocacy work, especially by NGOs and academic activists, has also been a successful addition in many cases (Aiken, 2016; Hamber, Mosikare, Friedman, \& Maepa, 2000; Lundy \& Mahoney, 2018).

There is an increasing amount of research that highlights the complex local processes of reconciliation and justice that often takes place out of sight of the mainstream TJ processes filling the gaps often left by overly-legal and top-down mechanisms that fail to take local practices and culture into consideration that can meet victims' needs. Well-documented cases now exist in Sierra Leone (Shaw, 2007), Uganda (Baines, 2007), Rwanda (Clark 2010), South Africa (Wilson, 2001), and Northern Ireland (Lundy \& McGovern, 2005; Panel of Experts on Redress, 2017), among many others. That said, the dominant view remains that 
when it comes to furthering wider TJ aims, local participation is insufficient by itself and there is a danger in romanticising the local where exclusions and power struggles exist and can be reinforced by some practices (Gready \& Robins, 2014; Huyse \& Salter, 2008).

Ensuring processes are genuinely locally owned, or that local communities have the resources and capacities to participate and fully engage is an ongoing challenge (Correa et al., 2009). NGOs and what Madlingozi calls "TJ entrepreneurs" have been criticised for "speaking for and about victims" and in so doing further perpetuating disempowerment (Madlingozi, 2010, p.210). Elite international professional and donor network rather than locally rooted movements dominate $\mathrm{TJ}$ often discouraging or obscuring the participation of victims (Gready \& Robins, 2014 2896). Official institutions can also instrumentalise victims and force for them to suppress their victimhood depending on the political context, or victims can be pressured to highlight their suffering publicly for political ends (Sprenkels, 2017).

Victims can find themselves reproducing their victimhood for the so-called "public good" through TJ mechanisms (Humphrey, 2002) with their participation coming to signify a social purpose outside of the victim's own needs (Hamber, 2009). Victims can be used to legitimise different political institutions whether symbolically or to justify the financial, political, legal and psychological effort to deal with political violence (McEvoy \& McConnachie, 2013). Others too have argued that TJ and victims' role in the process can be used to create a "veneer of legitimacy" (Snyder \& Vinjamuri, 2003), "window-dressing" (Lundy \& McGovern, 2008a) or "tokenism" (Taylor, 2014, p.23) rather than genuine engagement.

In short, despite some advancements, the main tools of TJ such as trials, inquiries and truth commissions are still largely driven by the needs of the state rather than victims (Robins, 2017, p.42). Although one could argue that the process has some benefit for the individual (discussed below), the social purpose of participation and the benefit of testimony 
or participation (such as compensation or even prosecution) will seldom overlap with the individual meaning of participation or meet all the individual's psychological and social needs (Hamber, 2009).

\section{Testimony, healing and the treatment of victims}

It has been routinely asserted that $\mathrm{TJ}$ processes, and especially those utilising public testimony are psychologically beneficial to victims (Agger \& Jensen, 1990; Minow, 1998). Moon argues that trauma and catharsis have become integrally linked into TJ and has become "almost axiomatic to postconflict state-building" (Moon, 2009a, p.71). However, TJ has yet to make psychosocial support to victims central to its practice (Robins, 2017, p.48). Robins asserts that the "effectiveness of a victim-centred TJ process can then be measured in terms of its ability to address victims' needs" (Robins, 2011, p.79). If this is indeed true, then most TJ processes could not be defined as victim centred. Unfortunately, the research on victim experiences of $\mathrm{TJ}$ processes is at best ambivalent, and at worse $\mathrm{TJ}$ processes have been found severely lacking in their treatment of victims. When it comes to the mainstream of TJ (trial, inquires, truth commissions), although many human rights activists tend to valorise the “therapeutic value" of TJ processes to victims (Stover, 2004), research on victims' experiences of such processes are not overwhelmingly positive. Routinely it has also been shown that victims are ambivalent about the psychological outcomes of their participation in TJ processes (Hamber, 2009, 2015; Mendeloff, 2009). In some cases, giving testimony involved intense psychological suffering (Brounéus, 2008, p.71).

In relation to truth commissions, it has been found in numerous studies that for many victims the personal benefits and the relief experienced of speaking out are short-lived (Garkawe, 2003; Hamber, 2009; Hayner, 2001; Ross, 2003; Stover, 2004). When truth, justice or reparations do not follow speaking out (Hamber, 2009), or when survivors return to 
destroyed or impoverished communities (Stover, 2004), benefits of giving testimony are eroded. Put another way, giving testimony at a truth commission can be cathartic but is not necessarily therapeutic (Allan, 2000) and no substitute for a long-term therapeutic intervention for some survivors (Kaminer, Stein, Mbanga, \& Zungu-Dirwayi, 2001).

On the positive side, for victims testifying before the South African TRC, victims felt that breaking the silence and increased public awareness about their plight was important (Hamber, Nageng, \& O'Malley, 2000; Phakathi \& van der Merwe, 2007). However, more negatively, research suggests that most survivors felt their expectations (even if some were high) were generally not met by the process (Backer, 2005, 2006). The process was seen by many as disempowering (Byrne, 2004) with little psychological benefit (Kaminer et al., 2001) and communicating poorly with victims increasing their dissatisfaction (Becker, 2006; Hamber 2009). After the process victims also had no control over how their testimony was received or used by the public creating distress in some cases (Ross, 2003).

From a wider perspective, the failure to deliver justice in the eyes of most victims, as well as truth and the limited reparations process, impacted on the healing potential of the process (Garkawe, 2003; Hamber, 2009, 2015). Although victims that received additional support, in the form of counselling or participation in support groups, tended to record higher levels of satisfaction (Hamber, 2009; Phakathi \& van der Merwe, 2007). The findings in the South African case are mirrored in numerous other global findings (Brounéus, 2008, p.57). Therefore, although there is little evidence that truth-telling dramatically harms individuals, international research suggests that it is "highly dubious" that "formal truthtelling processes satisfy victims' need for justice, ease their emotional and psychological suffering, and dampen their desire for vengeance" (Mendeloff, 2009, p.592-593). Despite one of the justifications for victims participating in TJ being emotional relief, recovery and healing, empirical research shows "such strong claims are unsustainable" and such findings 
are surprisingly consistent across different $\mathrm{TJ}$ process such as trials and truth commissions (Karstedt, 2016, p.53).

\section{Conclusion: Victim-centric a bridge too far?}

In terms of TJ being victim-centric, it appears the consensus is that advancements have been made, and certainly in numerous official documents and in the mandates of TJ mechanisms the necessity to address victim needs is acknowledged. It is well established that many victims want to share their stories and feel it will offer emotional relief (Karstedt, 2016; Mendeloff, 2009; Stover, 2004), and have a desire for truth-telling, justice and accountability (Mendeloff, 2009). It is also important to remember, many victims are resilient and despite their suffering live rewarding and balanced lives, and most do not suffer from debilitating psychiatric problems (de Ridder, 1997; Hamber, 2019; Robins, 2011). However, it is widely accepted that the rhetoric surrounding $\mathrm{TJ}$ mechanisms and their positive impact on victims does not often match the reality. Living in ongoing poverty also exacerbates and shapes how victims understand justice and what is needed to redress the past (Robins, 2011). This raises questions as to how $\mathrm{TJ}$ processes can make a lasting impact or be genuinely victim-centred in its current form, and what lessons from TJ can offer when seeking to deal with the legacy of HIA.

\section{Historical Institutional Abuse: The Case of Northern Ireland}

Having laid out the discussions concerning the relationship between TJ and HIA, as well as the limits of the TJ field in relation to its victim-centred claims, the next section of the article considers these questions in relation to investigations into HIA in Northern Ireland. The case study is used to explore if lessons from TJ can be applied to the question of HIA with a specific focus on victims' experiences. Before doing this, however, the background of the investigation into to HIA in Northern Ireland is briefly discussed. 


\section{Background}

In November 2009, the Northern Ireland Assembly supported a motion for an inquiry into the extent of child abuse in Catholic Church and State-run institutions in Northern Ireland. The Inquiry into Historical Institutional Abuse Act (Northern Ireland) became law on 19 January 2013. The Historical Institutional Abuse Inquiry (HIAI), also known as the Hart Commission named after its chair, had two components, a confidential Acknowledgement Forum whose members listened to victims describe their experiences in residential institutions, and a Statutory Inquiry which heard evidence in public from victims, institutions and other relevant agencies. Victims could choose to participate in the Acknowledgement Forum only, or both components. Four-hundred and twenty-seven victims spoke to the Acknowledgement Forum (261 males and 166 females), and one individual gave a written account to the Forum. Threehundred and thirty-three victims gave evidence to the Statutory Inquiry, with 246 victims giving evidence in person and 87 individuals giving evidence via witness statements (Hart, Lane, \& Doherty, 2017). ${ }^{4}$ Public hearings were held between January 2014 and July 2016 investigating 22 institutions, as well as the circumstances surrounding the transporting of children from residential institutions in Northern Ireland to Australia. The HIAI had a wider remit unlike other inquiries in the UK and Australia that focused solely on sexual abuse. The HIAI examined sexual, physical and emotional abuse, neglect and unacceptable practices that took place in residential institutions for children (other than schools) between 1922 and 1995. The institutions under examination are a mixture of children's "homes" and training schools run by the State, by voluntary organisations and by the Catholic Religious Orders and Churches. ${ }^{5}$ The scope of the HIAI meant that victims of clerical child abuse that took place

\footnotetext{
${ }^{4}$ The breakdown of male/female is not given in the HIAI Report.

5 The HIAI investigations covered eleven voluntary homes run by Roman Catholic Religious Orders or other bodies such as Barnardo's, six Training Schools and other juvenile justice sector institutions; and five state run residential institutions. As well as the 22 institutions examined in the Public Hearings, the Inquiry also investigated abuse by Father Brendan Smyth of the Norbertine Order, and the operation of the Child Migrant Scheme (see Hart, 2017).
} 
outside residential institutions in other locations were excluded. The HIAI published its findings and recommendations on the 20 January 2017 (Hart, 2017; Hart et al., 2017). The four-year Inquiry found "evidence of systemic failings" in homes and other residential institutions run by the state, local authorities, churches and charities (Hart, 2017). There was also "evidence of sexual, physical and emotional abuse, neglect and unacceptable practices across the institutions and homes examined" (Hart, 2017; Hart et al., 2017, p.8-42). In general, victims welcomed the Report and its findings (Morris, 2017).

\section{Methodology}

Research on the HIAI was carried out between October 2014 and July 2017. Forty-three faceto-face semi-structured interviews were conducted with victims who had attended the HIAI. ${ }^{6}$ This included eighteen women and twenty-five men; the mean age was 56 and 65. All of those interviewed in this convenience sample had spoken to the Acknowledgement Forum and testified publicly. The sample reflects a broad cross-section of victims of historical abuse who were resident in the full range of residential institutions within the Inquiry remit. The three main victims' groups' and legal representatives facilitated access to potential interviewees. ${ }^{7}$ A considerable period was spent building trust and working collaboratively with victims' groups. A Panel of Experts on Redress was established in collaboration with survivor groups and several reports were co-created and published (Panel of Experts on Redress, 2017, 2018). Interviews were carried out across Northern Ireland; a small number took place in the Republic of Ireland (two) and England (four). The purpose of the face-toface interviews was to ascertain victims' motivations, expectations and justice needs, as expressed by victims themselves. A fundamental research question was the extent inquiries

\footnotetext{
${ }^{6}$ The interviews were part of a wider study that included focus groups and analysis of Inquiry transcripts; and interviews with Former Child Migrants in Australia.

${ }^{7}$ The three main victims' groups are Survivors and Victims of Abuse (SAVIA), Survivors North West (SNW) and Rosetta Trust.
} 
were survivor-centred from the perspective of victims. Victims were asked in interviews, through a range of questions, to describe and assess their experiences of the HIAI. The final part of the interview focused on identifying their needs and what could be done to repair the damage (as far as is possible). However, the aim was to enable voice, rather than restrict or structure responses so victims were given the space to explore in their own words what they wanted, and why. The interviews were between one and two hours long. They were recorded, transcribed, and thematically analysed with text segments coded and tagged; frequency coding was also undertaken. The emerging themes were cross checked, synthesised and discussed at length with the research assistant; and discussed informally with key representatives of survivor groups. In addition, extensive analyses of oral evidence transcripts, specifically on responses to redress questions, were carried out. Anonymised transcripts of evidence to the Inquiry are available on the HIAI website (HIAI, 2016).

\section{Findings}

This section critically explores victims' experiences and assessments of the Northern Ireland Historical Institutional Abuse Inquiry (HIAI) focusing on five interrelated themes: motivation for participation, the victim-centric nature of the HIAI, as well as victim participation, trauma, and needs.

\section{Motivations and expectations}

The main motivations victims gave for taking part in the HIAI was acknowledgement $(\mathrm{N} 19=45 \%)$ and to have a voice $(\mathrm{N} 15=34 \%)$. As one victim told the Inquiry:

I think we should have our justice, our voices heard. There are some of us that's not here today. They're gone. This is the voices for us all, all, to let the world, let the people know what happened in those institutions that shouldn't have happened; that the children 
should have been loved, cared for, not treated the way they were. [HIA Transcript: HIA 7]

A recurring theme in interviews was that victims wanted to be believed; overwhelmingly they sought vindication, validation and restoration of dignity:

We were sitting in the room and I said Jesus, what are they going to ask? Are they going to believe us? Are they going to believe us because they are going to say that was so long ago and that's the way times were...I was afraid...Y You still felt that you were of no importance and your story wasn't important enough for people to listen to and yet, I was there with the hope of giving it... [Int: F, Jan 2017]

Participation was not easy for many victims as some had not disclosed to their family that they had been in residential "care" and had suffered abuse as a child. Most victims had never spoken publicly about their experiences; some had gone to the Inquiry in secret:

I have a wonderful family, whom I love, and they took me in and cared for me and loved me, and I have two wonderful children as well, and it breaks my heart that I haven't told them that I am doing this, and my children don't even know that I am adopted, because I am too ashamed to tell them unfortunately. [HIAI Transcript: HA423]

\section{Victim-centric?}

As with TJ processes, what makes public inquiries victim-centred remains unclear. One of the main mechanisms for attempting to achieve this in the HIAI was the Acknowledgment Forum. The Acknowledgement Forum sought to provide "an opportunity for victims and survivors to recount their experiences on a confidential basis" (Hart et al., 2017, p.5). The Forum was private, confidential and had therapeutic aspirations seeking to hear testimony and accept without challenge. Similar to a truth commission, the Acknowledgement Forum purpose was to provide an opportunity for victims to give an account of the abuse suffered.

Out of the 43 interviews conducted with victims, more than half said that the Acknowledgement Forum was a positive experience and they valued the space to recount 
their experience, be listened to and believed. Victims said the Forum conferred acknowledgement $(\mathrm{N} 23=53 \%)$, gave voice $(\mathrm{N} 21.5=50 \%)$ and overall it was regarded as "helpful" (N17=39\%). Most described the Forum as meeting their needs to be listened to, without judgement and challenge:

The Acknowledgement Forum personally brought a sense of relief without being intrusive or judgemental...While the Acknowledgment Forum provided a relaxed environment, I can’t say the same for the statutory element. [Int: M2, Nov 2015]

Some victims were of the opinion that the Acknowledgement Forum was all that was required and that the more intrusive Public Inquiry was perhaps not necessary. As one victim put it, "You could have actually written the report just on the Acknowledgement Forum" [Int: M5 Nov 2015]. For many the Forum was a positive first step in breaking the silence and denial, however, only a small number described the experience as healing or cathartic $(\mathrm{N} 8=18 \%)$. Furthermore, a sizeable number of victims said they "felt exposed" or "vulnerable" $(\mathrm{N} 17=39 \%)$ and experienced longer term emotional consequences $(\mathrm{N} 12=29 \%)$ after attending the Forum. This was compounded by linked processes, for examples, when victims received their testimony in the form of a written statement in the post to their home, which created new vulnerabilities:

A lot of our guys would have gone more or less secretly... and then a letter arrives in your post box with 15 pages or whatever...So someone is going to have to go off on their own and read through their statement word for word - and that's a point of vulnerability. [Int: M 5, Nov 2015]

There were mixed views as to the adequacy of support provided during and after the Forum. Some said that adequate support and help was provided (29\%), others felt more support was needed (37\%), while others still were highly critical: 
To me, if a cup of tea and a wee squeeze of my hand was my counselling, then they done a good job, then they done a good job; but to me they done an awful job. [Inter: F2, Jan 2016]

Victims groups reported concerns about support services to the media in the first year of the HIAI's existence. Although the HIAI felt they had made every effort to ensure sufficient emotional support, victims' groups felt they had to "pick up the pieces" (BBC, 2013).

\section{Participation}

The HIAI stated that it was determined to "engage as many victims as possible to persuade them to come forward" (Hart, 2017). It is estimated that 27,738 children $^{8}$ were resident in the 22 institutions investigated within the Inquiry timeframe 1922 to 1995. It is unclear how many of those individuals are still alive. If we consider the numbers who engaged in the Inquiry (438 persons engaged the Acknowledgement Forum and 333 gave evidence to the statutory inquiry (Hart, 2017, p.6-10\} the take-up rate appears low. Drawing on the literature, there are many reasons why victims may have decided not to participate: shame, stigma, fear, secrecy, ill-health, vulnerability and the prospect of psychological difficulties, or lack of knowledge about the process.

But what of the experience of those who did participate? Chiming with the many TJ processes explored earlier, according to most of the victims' interviewed, participation in the HIAI was restricted to giving testimony and superficial consultation. When it came to giving testimony initially victims were hopeful (and ambivalent) about the process, but later this tended to move toward disappointment. Following initial official consultations with victims, mixed views are evident:

\footnotetext{
${ }^{8}$ The figure of 27,738 children comes from a PowerPoint presentation by The Executive Office (EO) $30^{\text {th }}$ January 2018, copy on file with authors. The figure 27,738 was compiled from the HIAI website.
} 
There were consultations with some of ourselves...In them early days we trusted them, I trusted them. I thought that they knew better. They didn't know better. We trusted them wholeheartedly and you know they were nearly putting words into our mouths. [Int: F4 July 2016]

One victim who participated in the official consultation process, reflecting the views of others, noted that "in the rush to get the inquiry started we overlooked some things". Another believed that victims did not have the capacity to influence the shaping of the Inquiry.

You have to understand that we're not equipped to deal with the behind the scenes work that goes on in an inquiry, it's a lot of professional people dealing with a lot of professional stuff, and our voices probably meant only $2 \%$ out of $200 \%$ of that inquiry... so there was a lot that we don't know about...[it's]...right out of our depths. [Int: M7, Nov 2015]

Thirty-two percent $(\mathrm{N} 14=32 \%)$ of victims interviewed raised concerns about the Statutory Inquiry; where it was located and the process of giving evidence. The following quote highlights this:

We were rather excited that it was going to be victim centred and we had made it all about the victims and survivors. Unfortunately, all of a sudden, the Inquiry was moved to Banbridge, in the country, in a place that nobody knew, a mainly Protestant area, where many Catholics were fearful of even going to, or didn't even know where it was. So that was quite a shock; and then the Inquiry was going to be held in a courthouse...it seemed we were on trial...[Int: F4 July 2016]

This view was shared by many, with the setting and environment described as "inappropriate and intimidating" $(\mathrm{N} 12=29 \%)$. This stem, partly, from the presence of alleged perpetrators, members of institutions and Religious Orders being in close proximity to victims' in the coffee and waiting room areas, and in public hearings. This created an unsettling environment: 
The place was packed...the nuns were there, the de La Salle Order were there, you know, drinking out of the same cups, going to the same toilet, sitting at the same seating area, that was very threatening and humiliating and it shouldn't have been allowed. [Int: F4, July 2016]

Testifying in public was also stressful and traumatic, and the court-like setting compounded anxiety.

I found that whole process a little bit intimidating...it's just that formal structured atmosphere when you go in and there's Sir Anthony and the Panel sitting there and the place is full of media and social workers - and there's big TV's and computers. [Int: M10, Nov 2016]

The above accounts of participation in the design of the HIAI reveal that victims' ability to exercise agency was limited. Although victims were given the right to tell their story this did not amount to full participation. That said, survivor representatives exercised what could be termed non-testimonial agency. For example, victims' requested changes to the HIAI terms of reference specifically to extend the HIAI timeframe from 1945 to 1922 in order to include more victims. The terms of reference were amended meaning an additional 51 victims could apply to the Inquiry (Hart et al., 2017, p.4). But as can be seen, their influence did not fully ensure the overall experience was empowering. A cynical reading of the consultation process, and the participation of victim groups, was that it served to legitimate the Inquiry rather than fully address victim needs or shape the Inquiry in the way they wanted. For some it was a "tick the box exercise" [Int: F4, July 2016] and consultation was superficial:

...The government and the inquiry had no other choice but to talk with us and promise us and give the world, and didn't give us the world... But they needed us on board because it [the Inquiry] was for us. [Int: M7, Nov 2015]

\section{The trauma of testimony}

As already discussed in the context of TJ, the therapeutic model assumes that telling one's 
story is cathartic and can contribute to healing. It has also found, as noted, that the reality for most TJ mechanisms is a mixed picture at best. This was confirmed in the case of HIAI. Over half of those interviewed stated that it was an "emotional experience" (N24=55\%) and nearly half described it as "traumatising" (N20=47\%), with almost as many saying they "felt vulnerable" (N18=42\%). In short, giving testimony was far from therapeutic:

I'm thinking, I'm going here to find out about myself and it's going to be better and I'm going to know who I am and what happened. But instead I opened this big can of worms and it exploded all around me. [Int: F2, Jan 2016]

Negative experiences of participation in the HIAI led to the resurfacing of "old" problems; as one victim put it: "I came into this thing as a balanced individual and come out of it unbalanced - there's lots of people that have come out of it unbalanced - they need help" [Int: M25, Sept 2016]. Victims described a sense of being the subject of inquiry rather than being the party listened to. Others said they had experienced longer term emotional consequences $(\mathrm{N} 12=29 \%)$ after attending:

It never goes away. As it is at the moment, I am having more problems now that I did before the Inquiry. It's bothering me more, stopping me from sleeping, getting up during the night. I'm thinking about it more now... [Int: M14, June 2016]

Victims spoke in interviews of being re-traumatised and re-victimised, thus compounding the original trauma and potentially causing psychological harm. For example:

My only way of coping was to try and claw back some kind of control of what was going on around me cause I felt like I had a filing cabinet in my head and all the drawers had exploded open, and I was down on the ground trying to put all the pages back in...this woman [barrister]... now she's for me; if she's representing me why am I feeling like I have to watch her like a hawk? I'm meant to be feeling like she's my safety net and instead I'm feeling like I'm fighting her on the stand...I had to keep nipping my leg in the stand, don't you cry, don't you, and I had to cause if I cry I lose it. [Int: F2, Jan 2016] 
The Inquiry stated that, public hearings would "be conducted in an inquisitorial fashion", witnesses would not be "subjected to inappropriate or unnecessary cross examination" and this was "greatly assisted by the skilful way in which Counsel took all witnesses through their evidence in a sympathetic fashion" (Hart et al., 2017, p.12 para 28 \& 30). Despite these claims a significant number of victims perceived the proceedings differently. Some said that it was like a court $(\mathrm{N} 17=39 \%)$ and others that they "were on trial" $(\mathrm{N} 17=39 \%)$. A small number said it was an "intimidating experience" $(\mathrm{N} 8=18 \%)$; others felt "victimised" $(\mathrm{N} 8=18 \%$ ). Put another way, 16 out of 43 victims interviewed said they felt victimised or intimidated:

I felt that it was a court rather than an inquiry... But it was terrible. It was the worst day ever. And to bring up nearly 60 years of stuff that you've buried in your head, you know. How do you remember something 50/60 years ago? So I felt I was being cross examined...[Int: M12, Jan 2016]

This made some feel like they "were offenders" and this made some regret their decision to testify:

I wish personally I'd never done it, honestly... That's how I feel - I just - because I was on anti-depressant tablets - and then I'm on more now - and I had to up my dose too...I feel as if - you know - I'm the bad person - the victim you know - after the way we were treated in Banbridge court was actually the worst feeling. [Int: F1a, June 2017]

In short, the HIAI self-professed the hearings would be inquisitorial, this is common with inquiries of this type, but in reality, most are highly adversarial and employ intrusive crossexamination tactics to discredit complainants (Corby et al., 2001). This seems true of the HIAI. Not only did some victims feel they had little control over procedures, they were in a process which they believed constrained their voice or that they "struggled to be heard" (N16=37\%). Victims thought that they would have the opportunity to "tell their stories" in their own way. As one victim put it: "It was what they wanted to ask, not what we wanted to 
say..." [Int: M13, Jan 2016]. This did not allow for nuanced storytelling.

A further cause for concern was the untimely disclosure of personal and sensitive information in the briefing meeting with the Inquiry's barrister prior to testifying and the potential psychological impact of such disclosures. This was deeply distressing and disempowering; $40 \%$ of those interviewed raised this as a concern.

Timely disclosure was a big difficulty, in fact the people who got told stuff, who were given stuff 10 or 15 minutes before going in to testify, ended up really traumatised through the evidence giving part at the statutory inquiry. [Int: M5 Nov 2015]

Victims' representatives said that they raised their concerns with the HIAI including the environment, briefing sessions, preparation, support services and how victims were cross examined. According to interviewees, these concerns were not acted upon compounding their dissatisfaction. Overall this left sizeable numbers of those who participated in the process deeply dissatisfied and with additional psychological concerns.

In a similar way to the TJ processes explored earlier, the relief that was experienced by some from testimony was short-lived and the full consequences of giving testimony became more evident over time. The following quote illustrates the after-effect of testimony:

I was talking to my son....in the middle of the conversation he says "yeah - I read your statement. It's on-line". I didn't know all the statements I'd written are on the HIA website. Cause obviously I'd been promised high level anonymity - and obviously my name wasn't on it; but there was enough little bits of information in it for him to be able to go through them all and find mine...So I did feel a bit vulnerable... [Int: M/Nov 2016]

Another victim describes the impact of giving public testimony and the regrets that he now has:

My biggest regret is that the first statement I made was taken by the Religious Orders and I was very, very bland. It's what was not written in the statement that's come to bug 
me now, and when you hear what other people have said and what you said...yeah that was right that brutality did happen...I think I did a dis-justice to what really went on in these places...If I had the opportunity to do it again I'd do it differently... [Int: M 25, Sept 2016]

Others said that they had revealed more than they wanted to, and this left them feeling vulnerable as the following examples illustrates:

The statutory element was more formal and intrusive, even to the extent you were left in isolation, re-traumatised and re-victimised. Some of the material about you was placed in a public arena....and that only managed to tarnish my integrity and affect my selfesteem...While I can understand the statutory element was a fact-finding process, it however only managed to achieve character assassination. The months that followed have resulted in my seeking counselling; my whole wellbeing was at an all-time low even to the extent I contemplated suicide... While I voiced my experiences, sadly the retelling left a stain on my character. The statutory inquiry failed to protect my person. (M, 10 June 2018). ${ }^{9}$

Taken together, some victims believed that the HIAI had damaged their integrity and/or their family exposing unnecessarily and intrusive information. This raises questions about the correlation between voice and dignity with regard to testimony. It also reinforces research carried out by Ross (2003), mentioned earlier, that showed that recounting harm does not guarantee that it will be received in ways testifiers might wish and be harmful to the sense of self. In the HIAI the public access to testimonies was often disempowering and had personal consequences beyond their control. Of the 43 victims interviewed, $42 \%$ said that they had "insufficient information and understanding" of the public hearing procedures. Just two victims $(5 \%)$ said they were well informed, the vast majority felt unprepared. This all raises questions of ownership of public narratives, the victim-centered nature of the process and if adequate information was supplied to give genuine informed consent.

\footnotetext{
${ }^{9}$ This individual was interviewed and subsequently sent a letter with further details.
} 


\section{Victims' needs}

In this article, we have thus far argued that the starting point in any victim-centred process should be to determine victims' needs. This is not easy. Victims are not a homogenous group and their experiences and needs vary and can change over time, as noted earlier. In terms of the HIAI, victims had expectations that the HIAI would provide a platform to fulfil their perceived duty to testify, to tell their story, validate their past and this would in some way be therapeutic or provide justice. As we have seen, the experience of giving testimony was far from therapeutic for some. However, the HIAI provided acknowledgment, raised public awareness about abuse and provided vindication and validation for many victims which is important. It satisfied a perceived duty to testify and bear witness. Again, this corresponds with the TJ literature explored earlier. However, whether the HIAI was perceived as ultimately valuable to those interviewed was often contingent upon the outcomes of the Inquiry, and particularly, redress both symbolic and material. Apologies were perceived by some $(\mathrm{N} 27=63 \%)$ as an important:

They should apologise, in a big way. They should get down on their knees, and say they are sorry for what they did. [Int: F6, Sept 2016]

Some were more cynical and considered apologies pointless and opened the door for insincerity, i.e. those responsible will apologise not " because it's wrong" but "because it's a media thing and that is what we need to do" [Int: F15, Sept 2016]. Victims strongly expressed the view that apologies had little worth if there was no commitment to other justice measures and needs, again echoing the TJ literature. The HIAI clearly heard the desire for an apology making such a recommendation in its final report (Hart et al., 2017).

Compensation was a priority for many. Almost $80 \%$ (N34.4) cited compensation as a desired outcome of the HIAI. Some found it difficult and offensive to "put a price" on their suffering. As one victim put it: "what price is a childhood...You can't put a price on that" 
[Int: F19, July 2016]. But when compensation was desired it was not seen in isolation. For example, compensation was also linked to repair or rehabilitation measures. For many victims, historical abuse is not historical; they live with the consequences every day. This was a constant theme in interviews. Many talked about coping with trauma and living with associated mental health concerns, as well as alcohol and substance abuse, self-harm, anger and suicidal ideation, and that historical abuse limited their socio-economic horizons. Measures identified by victims to help repair and rebuild shattered lives included healthcare services, long-term counselling, education and training, intergenerational needs and reunion with family/siblings. Loss of opportunity was frequently cited and linked to transgenerational needs. Victims stated that measures should extend to their dependents who have also suffered as a direct consequence of the inter-generational effect of institutional abuse:

I know a few of our people who are hoping to get money to help their children, because some of our people's children's children or even grandchildren are still in that poverty trap because of the lack of knowledge their granda had or their father had, or lack of education that they had. So I think redress is very important, very important. [Int:M8, Nov 2015]

In most interviews, access to records emerged as an essential element of redress. A major source of distress, trauma, struggle and frustration for victims was gaining access to their personal historical files and sourcing meaningful information. Many felt an acute loss of identity not knowing the full extent of their lives as children in care.

Redress can also be symbolic. The HIAI specifically asked victims about their views on a form of memorial to pay tribute to the harms suffered. There were mixed views on a memorial. In interviews some welcomed the idea as a form of acknowledgement and remembrance. Others were strongly opposed to it as a painful reminder that might even be harmful (13\% were in favour and $26 \%$ were not). As one victim said: 
...I know a lot of people who has went through abuse and that [monument] is going to be like a beacon calling them no matter when things are bad in their life. They're going to go to it and they're going to blame this statue for everything; and you know they're going on their worst day. Someone is going to be found dead at that monument... [Int: F2, Jan 2016]

In the final instance, the HIAI recognised the ambivalence victims had to a memorial, noting many victims did not want "to be reminded of their experiences as children in residential institutions" (Hart, 2017, 43). But recommended a memorial be erected at the local parliament to "remind legislators and others of what many children experienced in residential homes" (Hart, 2017, p.43).

A key motivation for participating in the HIAI for many victims was to get "the truth". They explained this in terms of needing to "understand what happened". For some, it was about gaining access to new information, create an authoritative record and get answers to personal questions. Others were more cynical. These individuals said that they already knew the truth; all they wanted was acceptance of responsibility and accountability. In interviews, a sizeable majority of victims $(\mathrm{N} 31=71 \%)$ expressed a strong desire for those who abused them to be criminally prosecuted through the courts. This was a necessary part of the healing process for some and motivated them to go through the trauma of giving oral evidence to the HIAI. The importance of accountability as a justice goal was underscored by many victims (39\%), although this did not necessarily mean all victims sought criminal prosecution. What they wanted was individual perpetrators to be held to account. Accountability could take different forms and was linked to accepting responsibility and validating the experiences of victims. A constant theme in interviews (and in the transcripts) was that victims were driven to participate in the HIAI to ensure that it would "never happen again". An analysis of the HIAI transcripts show that, a common response to counsel's question on redress was "changes to the system" to guarantee a non-repetition of violations. 


\section{Recognising needs: The final report}

The HIAI in its final report made a set of recommendations that go some way to recognising the needs outlined above, i.e. for compensation, an apology, a memorial, specialist care and assistance (counselling and social support for example with housing and education) and for the establishment of a Commissioner for Survivors of Institutional Childhood Abuse (COSICA) (Hart et al., 2017, pp.227-256). However, these do not cover the full range of needs identified (e.g. access to files, non-repetition, institutional reform, justice, compensation, accountability) (Lundy \& Mahoney, 2018; Lundy, 2020). At the time of writing, victims remain disappointed but are equally engaged in persistent lobbying through a bottom-up collaborative initiative to influence the legislation being passed to implement redress following the HIAI (Panel of Experts on Redress, 2017, 2018). Most recently victims managed to achieve "significant changes" to the current legislation reflecting better their needs (HIA (Northern Ireland) Bill [HL], 2019).${ }^{10}$ However, viewed holistically, if Robins (2011) is correct in asserting that the effectiveness of a victim-centred process can be measured by its ability to address victims' needs, then the HIAI cannot be unequivocally considered a victim-centred process.

\section{Learning from Transitional Justice?}

If we were to draw on TJ as a framework for HIA, in broad conceptual terms Gallen (2016) makes a strong argument that TJ provides framing principles that are helpful and extends thinking and practice around HIA. The fundamentals of TJ such as the right to truth, justice, and reparations, as well as seeking institutional reform and guarantees of non-recurrence of violations provide a holistic template to which HIA might aspire. It is clear, for example, in

\footnotetext{
${ }^{10}$ Letter to Secretary of State for Northern Ireland from Northern Ireland political parties agreeing to changes to HIA draft redress legislation, copy of letter on file with authors.
} 
the Northern Ireland case that the focus of the HIAI was limited, not considering all of the aspects a wider TJ focus might consider (e.g. justice, non-repetition, societal transformation, institutional change, education in schools post-violation). What has also been shown through the HIAI case study, however, is that many of the flaws of TJ mechanisms discussed at the outset of this article concerning the failure to make processes genuinely victim-centric have been replicated when dealing with victims of HIA.

To this end, if HIA inquiries are to learn anything from the TJ field, it is that to address victims' needs is a shared challenge. We now outline five broad areas for consideration, drawing from lessons - both positive and negative - in the TJ field, that can strengthen the victim-centred nature of approaches to HIA.

\section{Victim needs as the engine for addressing the past}

In the TJ field, as noted earlier, there are numerous statements, charters and international levels of guidance about ensuring victim-centrality, but these have had limited effect. TJ teaches us that more is needed. It is often assumed that treating victims with due process and respect during participation in $\mathrm{TJ}$ processes equates with being victim centred. Of course, it is vital for TJ and HIA processes that complementary processes are set in place such as counselling, witness briefing and debriefing, victim-sensitive questioning, support to assist victims to attend processes, avoiding delays, supporting families and NGOs to offer additional support, as well as using culturally appropriate rituals to dealing with harm. Detailed analyses of how victim participation can be improved in a practical sense have been developed in the TJ field and could be drawn upon (Sprenkels, 2017; Taylor, 2014). But participation restricted to the design stage, implementation and follow-up phases of TJ mechanisms have been found to be too constraining (Sprenkels, 2017). A wider focus is needed. Full participation is a political issue and should equate with increased power and 
influence (Sprenkels, 2017), and, engage with the wider context of violations.

Victim needs cluster around certain issues (e.g. compensation, justice, and acknowledgement) as the HIAI case study has shown, but at the same time needs are notoriously difficult to measure or catalogue. Needs are also dynamic continuing to change and evolve (Hamber, 2009; Robins, 2011, 2017; Simpson, 2002). Although a majority of victims wanted justice in the HIAI case study, they had different understandings of what justice meant, e.g. retributive justice, public apology and/or acknowledgment. Victim needs should be at the centre of the HIA processes and support designed according to those needs. Importantly, needs should not be assumed as has often been the case in the TJ field. It has been shown in this article that needs extend beyond addressing psychological distress or offering space to share one's story, but rather distress is integrally linked to unresolved issues such as the lack of truth or justice, access to personal records, as well as the current socioeconomic status of victims.

As was noted by victims in the HIAI case study, sometimes needs were broad, some felt their institutional abuse had prolonged a "poverty trap" with long-term inter-generational socio-economic consequences. If you begin with needs, then it will become impossible to restrict HIA investigations only to consider violations of bodily-integrity and not more comprehensive questions of social exclusion, marginalisation, and economic deprivation often exacerbated by social, ethnic and gender positioning. Such an approach would invariably challenge the idea that it is only legal mechanisms that are at the heart of TJ. Victims' needs, from the everyday through to those linked to directly to the violations they have suffered, should be the starting point of any HIA process rather than beginning with seeking a balanced menu of options such as truth commissions, trials and compensation packages as TJ often implies. 
This is not to say that TJ, in the limited sense of focusing on mechanisms, has no place. Knowing why events happened or having events reframed through knowing the truth (the cognitive component of recovery) and being provided with the space to share your suffering beyond once off testimony (the socio-affective response), are both needed for victims to benefit from TJ processes (Karstedt, 2016). Those who spoke before the HIAI clearly expressed both of these needs, although many felt being given space for testimony was attended to more than issues of truth and justice (e.g. access to their files and holding perpetrators to account). Over-valueing the therapeutic impact of testimony alone needs to be avoided.

In the HIAI victims also wanted guarantees of non-repetition as noted, i.e. that it would "never happen again" and "changes to the system" would follow. It has been shown that the attainment of truth, justice, reparations and guarantees of non-repetition are integrally linked to how victims recover from political violence (Hamber, 2009). That said, there is no standardised approach as a genuinely needs-based approach must be built from the bottom up mindful of the entire social, cultural and political context of the violations and their interrelated nature. This should guide the entire endeavour framing TJ and HIA approaches with a much broader time horizon than what is offered by specific TJ processes. Furthermore, there are few studies that evaluate survivors' perspectives of historical child abuse inquiries and victims' needs (e.g. Claes \& Clifton, 1998; Daly, 2014b; Law Commission of Canada, 2000; Lundy, 2016, 2020; Minister of Indian Affairs and Northern Development, 2000), more empirical research on the subject would assist in widening the debate about victim needs.

\section{Forms of support beyond transitional justice mechanisms}

The field of TJ has broadened significantly in the last decade, and a wide range of processes are all now considered part of the wider field of TJ. For example, implementing institutional 
transformation, memorialisation and building museums, opening archives, rewriting official histories and altering school textbooks, offering apologies, statements of acknowledgement and building the interrelationship between TJ and development. Grassroots dialogical and truth sharing at a local level that operates outside of state-sanctioned approaches to the past should also be part of any transitional justice process (Lundy, \& McGovern, 2008; Nagy, 2013). If work on HIA is to begin to lend or link its work more closely to TJ, it would be worth critically exploring the broader use of TJ into different contexts (Gready \& Robins, 2014, p.345). Linking TJ and HIA should, therefore, seek lessons in the fields of historical dialogue (Barkan, 2009), education and TJ (Ramírez-Barat \& Duthie, 2017) and restorative justice (Gavrielides, 2012; McAlinden \& Naylor, 2016), to name a few, and not merely focus on learning from legal mechanisms such as truth commissions, inquiries or trials. If HIA is to be genuinely victim-centred, the long-term nature of recovery and the life-long impact of severe political violence and abuse must be recognised.

\section{Preventing the instrumentalising of victims}

The critical scholarship on TJ explored earlier in this article warns of the danger of an overly legal and institutional focus, and victims being used for political ends. In particular, how different mechanisms such as inquiries or truth commissions can be used to legitimise the state or other institutions rather than challenging neglect by the state and other actors (see McAlinden, 2013). Of course, in the process, the silence about HIA is frequently shattered, and this is important, but it raises questions, as have been raised in the TJ field, about the role and place of victims in such processes. Primarily are their individual and specific needs being met, or are these, or at least some of these, sacrificed in the name of state-building when it comes to TJ or in terms of HIA are inquiries established to satisfying the public's need to know that something was being done and/or for governments to protect themselves from 
accusations of indifference. In the HIAI case study specifically, as noted earlier, some victims questioned the nature of the consultation process and whether it took their views fully on board or was, a "tick the box exercise" aimed at legitimising the process. Furthermore, if victims felt "out of our depths" or lacking capacity and resources to engage with the process fully as quoted earlier, the whole notion of meaningful participation becomes questionable. Therefore, being acutely aware of the power processes at play that shape the responses to violations especially by governments in TJ and HIA processes must be central to any shared lesson-learning or cross-fertilisation of thinking in the respective areas.

\section{Supporting local initiatives and advocacy}

If the systemic picture involves violations by or neglect by the state, it can also be expected that investigatory and truth commission bodies, often established by the state it is investigating, will often find its ability to carry out wide-ranging inquiries and investigations curtailed. To this end, civil society involvement, along with victim groups, academic activists and journalists investigating the full historical context, are all necessary to challenge and deal with the political nature of such investigations and push back against official narratives or desire to produce a contained and time-limited process of investigation that might focus on individual rather than systemic culpability. Not to mention the fact that involvement in advocacy and social action for survivors of violence in a range of settings has been linked to trauma recovery (Hamber, 2009; Herman, 1992). As was briefly discussed above, nontestimonial advocacy by victim groups had an impact on the HIAI. In addition, the NI Redress Act recently passed through Westminster was shaped by victims' groups in Northern Ireland. This secured a more comprehensive compensation package than originally recommended by the HIA Inquiry (McCormack, 2019). However, for victim groups to play these roles, they need to be resourced and have adequate capacities for meaningful 
engagement (Garkawe, 2003; Sprenkels, 2017) and existing resiliencies built upon (Hamber and Gallagher, 2014). Some in the TJ field have argued that, through various mechanisms, commission or other truth-seeking bodies can serve to build the capacity of victim groups and build participatory processes that are beneficial to victims and the legacy of the body concerned (Correa et al., 2009). Once again, although legal mechanisms such as inquiries can be helpful, and have been helpful in some HIA cases (McAuliffe, 2017 outlines some for the successes), lessons from TJ urge one to ask more critical questions. Particularly to consider the utility of a focus that leans heavily toward official legal mechanisms such as inquiries, trials and truth commissions as the primary tools for investigating the past. Unofficial, civil society-led truth-seeking initiatives, for example, have been found to be effective in generating victim participation, sometimes more than official processes (Lundy \& McGovern, 2008b; Sprenkels, 2017). Drawing on lessons from the TJ field, supporting local initiatives such as memorialisation and storytelling, sponsoring advocacy work, as well as wide-ranging independent research and investigations into archives and past, should be recognised as central to any approach to HIA.

\section{Constructing systemic narratives of the past}

A final lesson that can be drawn from TJ that has relevance to the issue of HIA concerns how one goes about constructing narratives of the past and addressing systemic questions of why the abuse happened in the first place. Truth commission at least, in theory, offer much in this regard as they seek to establish the "cause, nature and extent" of violations (Hamber, 2009). Gallen sees benefit in using the TJ framework for HIA, as noted because it has a better chance of uncovering "the range of factors that contributed to the emergence of the crisis" and can "articulate multilayered conceptions of truth and responsibility" (Gallen, 2016, p.343). There is much merit in these arguments. On the whole, despite some wide-ranging 
academic works (O'Sullivan and O'Donnell, 2007; 2012), HIA inquiries themselves have not fully addressed the social and systemic issues to date. Often the institutional and social contexts that gave rise to violations are assumed to be addressed in the modern state, rather than the full explanations for why violations happened, and the need for ongoing institutional reform, monitoring and strategies for non-repetition (both state and at the community level) being a core part of post-HIA inquiry concerns. However, TJ mechanisms have equally struggled with this issue. Truth commissions have relied on individual evidence to build the story of the past, and the result has been that often processes have become individualised, focusing on specific victims or perpetrators. This may benefit some, but the individual culpability model does not get to the multi-layered conceptions of truth Gallen seeks. Equally, the limited mandates of many TJ processes exclude certain groups from participation due to restricted mandates or the process they choose for investigation.

The principle borrowed from TJ of seeking a full contextual truth would undoubtedly add weight to addressing HIA, but current TJ models of getting to this wider truth would need to be equally critically interrogated to achieve this. TJ mechanisms such as truth commissions, will not develop a multi-layered contextual narrative if their mandate does not refer to systemic issues, for example. Unless any $\mathrm{TJ}$ investigatory process or body is empowered and resourced to carry out investigations, inquiries and historical and archival research beyond what is received from testimony, the more comprehensive story will not be told. Put another way, a key lesson for HIA processes is that to truly address the past the focus must extend beyond the limited "scope of justice by engaging structural violence" (Nagy, 2013, p.71). It is only when the structural context of human rights violations is centre stage in any HIA process that the analytic and systemic promises of TJ can be realised. This also holds the key to truly understanding victim needs in the widest frame possible, opening the door to address such needs more effectively. 


\section{References}

Agger, I., \& Jensen, S. B. (1990). Testimony as ritual and evidence in psychotherapy for political refugees. Journal of Traumatic Stress, 3, 115-130.

Aiken, N. T. (2016). The distributive dimension in transitional justice: reassessing the South African Truth and Reconciliation Commission's ability to advance interracial reconciliation in South Africa. Journal of Contemporary African Studies, 34(2), 190202.

Allan, A. (2000). Truth and Reconciliation: a psycholegal perspective. Ethnicity \& Health, $5(3), 191-204$.

Arnold, B. (2009). The Irish Gulag: How the State Betrayed Its Innocent Children. Dublin: Gill \& Macmillan.

Backer, D. (2005). Evaluating Transitional Justice in South Africa from a Victim's Perspective. Journal of the International Institute, 12(2), 8-9.

Backer, D. (2006). Victims' Responses to Truth Commissions: Evidence from South Africa. In M. Ndulo (Ed.), Security, Reconciliation and Reconstruction: When the Wars End (pp. 165-196). London: University College of London Press.

Baines, E. K. (2007). The Haunting of Alice: Local Approaches to Justice and Reconciliation in Northern Uganda. The International Journal of Transitional Justice, 1, 91-114.

Barkan, E. (2009). Introduction: Historians and Historical Reconciliation. The American Historical Review, 114(4), 899-913.

BBC. (2013). Abuse inquiry criticised over level of victim support. 8 August 2013. Retrieved from https://www.bbc.co.uk/news/uk-northern-ireland-23611900

Bonacker, T., Form, W., \& Pfeiffer, D. (2011). Transitional Justice and Victim Participation in Cambodia: A World Polity Perspective. Global Society, 25(1), 113-134.

Boston College University Communications. (2018). Towards Transitional Justice: Remarks by Minister for Children and Youth Affairs Katherine Zappone [Press release].

Retrieved from https://www.bc.edu/bc-web/bcnews/nation-worldsociety/international/irish-conference.html

Brennan, C. (2015). Trials and Contestations: Ireland's Ryan Commission. In S. Swain \& J. Sköld (Eds.), Apologies and the Legacy of Children in 'Care': International Perspectives (pp. 65-68). London: Palgrave Macmillan.

Brounéus, K. (2008). Truth-Telling as Talking Cure? Insecurity and Retraumatization in the Rwandan Gacaca Courts. Security Dialogue, 39(1), 55-76.

Byrne, C. C. (2004). Benefit or Burden: Victims' Reflections on TRC Participation. Peace and Conflict: Journal of Peace Psychology, 10(3), 237 - 256.

CICA. (2009). Report of the Commission to Inquire into Child Abuse (Ryan Report). Dublin: The Stationery Office.

Claes, R., \& Clifton, D. (1998). Needs and expectations for redress of victims of abuse at residential schools. Final Report Submitted to The Law Commission of Canada. Ottawa: Law Commission of Canada.

Clark, P. (2010). The Gacaca Courts, Post-Genocide Justice and Reconciliation in Rwanda: Justice without Lawyers. Cambridge: Cambridge University Press.

Corby, B., Doig, A., \& Roberts, V. (2001). Public Inquires Into Abuse of Children in Residential Care. London: Jessica Kingsley Publishers.

Correa, C., Guillerot, J., \& Magarrell, L. (2009). Reparations and Victim Participation: A Look at the Truth Commission Experience. In C. Ferstman, M. Goetz, \& A. Stephens (Eds.), Reparations for Victims of Genocide, War Crimes and Crimes Against Humanity (pp. 385-414). Leiden and Boston: Martinus Nijhoff Publishers. 
Daly, K. (2014). Redressing Institutional Abuse of Children. Basingstoke: Palgrave Macmillan.

de Ridder, T. (1997). The Trauma of Testifying: Deponents' difficult healing process. Track Two, 6(3/4), 30-34.

de Waardt, M., \& Weber, S. (2019). Beyond Victims' Mere Presence: An Empirical Analysis of Victim Participation in Transitional Justice in Colombia. Journal of Human Rights Practice, 11(1), 209-228.

Duncalf, Z., Hawthorn, M., Davidson, J., Goddard, J., \& McMahon, W. (2009). Time for 'Justice': Research to inform the development of a human rights framework for the design and implementation of an 'Acknowledgment and Accountability Forum' on historic abuse of children in Scotland. Glasgow: The Care Leavers Association and the Scottish Institute for Residential Care.

Ferstman, C. (2010). International criminal law and victims' rights. In W. Schabas (Ed.), Routledge Handbook of International Criminal Law (pp. 407-419). London: Routledge.

Flynn, M. (2009). A harsh history of the horror. The Irish Times, (May 30). Retrieved from https://www.irishtimes.com/news/a-harsh-history-of-the-horror-1.774055

Gallen, J. (2016). Jesus Wept: The Roman Catholic Church, Child Sexual Abuse and Transitional Justice. International Journal of Transitional Justice, 10(2), 332-349.

Gallen, J., \& Gleeson, K. (2018). Unpaid wages: The experiences of Irish Magdalene Laundries and Indigenous Australians. International Journal of Law in Context, 14(1), 43-60.

Garkawe, S. B. (2003). The South African Truth and Reconciliation Commission: a suitable model to enhance the role and rights of the victims of gross violations of human rights? Melbourne University Law Review, 27(2), 334-380.

Gavrielides, T. (2012). Clergy Child Sexual Abuse and the Restorative Justice Dialogue. Journal of Church and State, 55(4), 617-639.

Gibson, J. L. (2002). Truth, Justice, and Reconciliation: Judging the Fairness of Amnesty in South Africa. American Journal of Political Science, 46(3), 540-556.

Glatz, C. (2013). Meeting on sex abuse expands reach, promoting global approach. Catholic News Reporter. Retrieved from http://ncronline.org/news/accountability/meeting-sexabuse-expands-reach-promoting-global-approach

Goldblatt, B., \& Meintjies, S. (1997). Dealing with the Aftermath: Sexual violence and the Truth and Reconciliation Commission. Agenda, 36, 7-17.

Golding, F. (2018). Sexual Abuse as the Core Transgression of Childhood Innocence: Unintended Consequences for Care Leavers. Journal of Australian Studies, 42(2), 191-203.

Gready, P., \& Robins, S. (2014). From Transitional to Transformative Justice: A New Agenda for Practice. International Journal of Transitional Justice, 8(3), 339-361.

Hamber, B. (2009). Transforming Societies after Political Violence: Truth, Reconciliation, and Mental Health. New York: Springer.

Hamber, B. (2015). Dealing with Painful Memories and Violent Pasts: Towards a Framework for Contextual Understanding. In B. Austin \& M. Fischer (Eds.), Berghof Dialogue Series 11. Berlin: Berghof Institute.

Hamber, B. (2019). Changing Context, Changing Lenses: A Contextual Approach to Understanding the Impact of Violence on Refugees. In T. Wenzel, B. Drozdek, \& J. Pont (Eds.), The Health of Refugees - an Interdisciplinary Perspective (pp. 3-22). New York: Springer.

Hamber, B., \& Gallagher, E. (Eds.). (2014). Psychosocial Perpsectives on Peacebuilding. New York: Springer. 
Hamber, B., Mosikare, N., Friedman, M., \& Maepa, T. (2000, 17-21 June). Speaking Out: The role of the Khulumani Victim Support Group in dealing with the past in South Africa. Paper presented at the Psychosocial programmes after War and Dictatorship Conference, Frankfurt, Germany.

Hamber, B., Nageng, D., \& O'Malley, G. (2000). "Telling it like it is.." Understanding the Truth and Reconciliation Commission from the Perspective of Survivors. Psychology in Society, 26, 18-42.

Hart, A. (2017). Launch of the Report of the Inquiry into Historical Institutional Abuse 1922 to 1995 [Press release]. Retrieved from https://www.hiainquiry.org/

Hart, A., Lane, D., \& Doherty, G. (2017). Report of the Historical Institutional Abuse Inquiry, Volume 1. UK: The Inquiry into Historical Institutional Abuse 1922 to 1995 and The Executive Office.

Hayner, P. B. (2001). Unspeakable Truths: Confronting state terror and atrocity. New York: Routledge.

Hearty, K. (2015). Legislating Hierarchies of Victimhood and Perpetrators: The Civil Service (Special Advisers) Act (Northern Ireland) 2013 and the Meta-Conflict. Social \& Legal Studies, 25(3), 333-353.

Henry, N. (2015). From Reconciliation to Transitional Justice: The Contours of Redress Politics in Established Democracies. International Journal of Transitional Justice, 9(2), 199-218.

Herman, J. L. (1992). Trauma and Recovery: From Domestic Abuse to Political Terror. London: Pandora.

HIAI. (2016). Modules: Index of Inquiry Modules. Historical Institutional Abuse Inquiry (Database of Inquiry Hearings). Retrieved from https://www.hiainquiry.org/modules0 .

Historical Institutional Abuse (Northern Ireland) Bill [HL]. (2019). Retrieved from https://publications.parliament.uk/pa/bills/lbill/2019-2020/0007/20007.pdf

Humphrey, M. (2002). The politics of atrocity and reconciliation : from terror to trauma. London; New York: Routledge.

Huyse, L., \& Salter, M. (Eds.). (2008). Traditional Justice and Reconciliation after Violent Conflict: Learning from African Experiences. Stockholm: International IDEA.

ICTJ. (2019). About Us. Retrieved from https://www.ictj.org/about

Irish Government News Service. (2017). Minister Zappone appoints a team of international experts to advise on burial site in Tuam during Dáil Statements on Mother and Baby Homes [Press release]. Retrieved from https://tinyurl.com/y4lkx3re

Jankowitz, S. (2018). The 'Hierarchy of Victims' in Northern Ireland: A Framework for Critical Analysis. International Journal of Transitional Justice, 12(2), 216-236.

Kaminer, D., Stein, D. J., Mbanga, I., \& Zungu-Dirwayi, N. (2001). The Truth and Reconciliation Commission in South Africa: relation to psychiatric status and forgiveness among survivors of human rights abuses. British Journal of Psychiatry, $178,373-377$.

Karstedt, S. (2016). The Emotion Dynamics of Transitional Justice: An Emotion Sharing Perspective. Emotion Review, 8(1), 50-55.

King, E. B. L. (2018). Transitional Justice and the Legacy of Child Sexual Abuse in the Catholic Church. Albany Law Review, 81(1), 121-143.

Law Commission of Canada (Ed.) (2000). Restoring Dignity: Responding to Child Abuse in Canadian Institutions. Ottowa: Law Commission of Canada.

Loughlin, E 'Katherine Zappone: "We will find the truth and achieve reconciliation", Irish Examiner, Cork, 10 March 2017. 
Lundy, P. (2016). Historical Institutional Abuse: What Survivors Want From Redress. Commissioned by the Panel of Experts on Redress. Retrieved from https://www.amnesty.org.uk/files/what_survivors_want_from_redress.pdf

Lundy, P. (2020), "I just want justice": A Critical Analysis of the Historical Institutional Abuse Inquiry in Northern Ireland, Éire-Ireland, Special Issue: Towards Transitional Justice in Ireland: Addressing the Legacies of Harm, 55: 1 \& 2, Spring/Summer 2020. Lundy, P., \& McGovern, M. (2005). Community, 'Truth-telling' and Conflict Resolution: A Critical Evaluation of the Role of Community-based 'Truth-telling' Processes for Postconflict Transition: A Case Study of the Ardoyne Commemoration Project. Belfast: Community Relations Council.

Lundy, P., \& McGovern, M. (2008). Whose Justice? Rethinking Transitional Justice from the Bottom Up. Journal of Law and Society, 35(2), 265-292.

Lundy, P., \& Mahoney, K. (2018). Representing Survivors: A Critical Analysis of Recommendations to Resolve Northern Ireland's Historical Child Abuse Claims. Annual Review of Interdisciplinary Justice Research (IJR), Representing Justice, 7(7), 258-291.

Madlingozi, T. (2010). On Transitional Justice Entrepreneurs and the Production of Victims. Journal of Human Rights Practice, 2(2), 208-228.

Mahoney, K. (2014). The Settlement Process: A personal reflection. The University of Toronto Law Journal, 64(4), 505-528.

Mahoney, K. (2018). The Untold Story: How Indigenous Legal Principles Informed the Largest Settlement in Canadian Legal History. University of New Brunswick Law Journal, 16, 198.

Mamdani, M. (2015). Beyond Nuremberg:The Historical Significance of the Post-apartheid Transition in South Africa. Politics \& Society, 43(1), 61-88.

McAlinden, A.-M. (2013). An Inconvenient Truth: Barriers to Truth Recovery in the Aftermath of Institutional Child Abuse in Ireland. Legal Studies, 33(2), 189-214.

McAlinden, A.-M. (2014). Deconstructing Victim and offender Identites in Discourses on Child Sexual Abuse: Hierarchies, Blame and the Good/Evil Dialectic. The British Journal of Criminology, 54(2), 180-198.

McAlinden, A.-M., \& Naylor, B. (2016). Reframing Public Inquiries as "Procedural Justice" for Victims of Institutional Child Abuse: Towards a Hybrid Model of Justice. Sydney Law Review, 38(3), 277-309.

McAuliffe, P. (2017). Comprehending Ireland's Post-Catholic Redress Practice as a Form of Transitional Justice. Oxford Journal of Law and Religion, 6(3), 451-473.

McCormack, Jayne (2019). Historical abuse: MPs pass long-awaited compensation bill. BBC News, 5 November 2019. Retrieved from https://www.bbc.co.uk/news/uk-northernireland-50296081

McEvoy, K., \& McConnachie, K. (2013). Victims and Transitional Justice:Voice, Agency and Blame. Social \& Legal Studies, 22(4), 489-513.

McEvoy, K., \& McGregor, L. (Eds.). (2010). Transitional Justice from Below: Grassroots Activism and the Struggle for Change. Portland, USA: Hart.

Mendeloff, D. (2009). Trauma and Vengeance: Assessing the Psychological and Emotional Effects of Post-Conflict Justice. Human Rights Quarterly, 31(3), 592-623.

Minister of Indian Affairs and Northern Development. (2000). Reconciliation and Healing: Alternative Resolution Strategies for Dealing with Residential School Claims. Retrieved from Ottawa: http://publications.gc.ca/site/eng/9.850157/publication.html

Minow, M. (1998). Between Vengeance and Forgiveness: Facing History after Genocide and Mass Violence. Boston: Beacon Press. 
Moon, C. (2009a). Healing Past Violence: Traumatic Assumptions and Therapeutic Interventions in War and Reconciliation. Journal of Human Rights, 8(1), 71-91.

Morris, A. (2017). Victims say they feel vindicated as damning historical abuse report published. The Irish News, 21 January 2017. Retrieved from https://www.irishnews.com/news/northernirelandnews/2017/01/21/news/victims-saythey-feel-vindicated-as-damning-historical-abuse-report-published-896041/

Nagy, R. (2013). The Scope and Bounds of Transitional Justice and the Canadian Truth and Reconciliation Commission. International Journal of Transitional Justice, 7(1), 5273.

O’Sullivan, E., \& O’Donnell, I. (Eds.). (2012). Coercive Confinement in Ireland: Patients, Prisoners and Penitents. Manchester and New York: Manchester University Press.

O'Sullivan, E., \& O'Donnell, I. (2007). Coercive confinement in the Republic of Ireland: The waning of a culture of control. Punishment \& Society, 9(1), 27-48.

Panel of Experts on Redress. (2017). Response to Historical Institutional Abuse Inquiry Redress Recommendations: The Panel of Experts on Redress Position Paper and Recommendations. Belfast: Ulster University. Retrieved from https://pure.ulster.ac.uk/en/persons/patricia-lundy

Panel of Experts on Redress. (2018). Briefing Paper: Proposed Improvements to HIA Inquiry Compensation. Belfast: Ulster University. Retrieved from https://pure.ulster.ac.uk/en/persons/patricia-lundy

Phakathi, T. S., \& van der Merwe, H. (2007). The Impact of the TRC's Amnesty Process on Survivors of Human Rights Violations. In A. R. Chapman \& H. van der Merwe (Eds.), Truth and Reconciliation in South Africa: Did the TRC Deliver? (pp. 116140). Philadelphia, Pennesylvania: University of Pennesylvania Press.

Ramírez-Barat, C., \& Duthie, R. (Eds.). (2017). Transitional Justice and Education: Learning Peace. New York: Social Science Research Council.

Redress. (2012). The Participation of Victims in International Criminal Court Proceedings: A Review of the Practice and Consideration of Options for the Future. London: The Redress Trust.

Robins, S. (2011). Towards Victim-Centred Transitional Justice: Understanding the Needs of Families of the Disappeared in Postconflict Nepal. International Journal of Transitional Justice, 5(1), 75-98.

Robins, S. (2017). Failing Victims? The Limits of Transitional Justice in Addressing the Needs of Victims of Violations. Human Rights and International Legal Discourse, 11(1), 41-58.

Ross, F. C. (2003). On having Voice and Being Heard: Some after-Effects of Testifying Before the South African Truth and Reconciliation Commission. Anthropological Theory, 3(3), 325-342.

Sarkin, J. (2007). An Evaluation of the South African Amnesty Process. In A. R. Chapman \& H. van der Merwe (Eds.), Truth and Reconciliation in South Africa: Did the TRC Deliver? (pp. 93-115). Philadelphia, Pennsylvania: University of Pennsylvania Press.

Sharp, D. N. (2015). Emancipating Transitional Justice from the Bonds of the Paradigmatic Transition. International Journal of Transitional Justice, 9(1), 150-169.

Shaw, R. (2007). Memory Frictions: Localizing the Truth and Reconciliation Commission in Sierra Leone. International Journal of Transitional Justice, 1(2), 183-207.

Simpson, G. (2002). 'Tell no lies, Claim no easy victories' A Brief Evaluation of South Africa's Truth and Reconciliation Commission. In D. Posel \& G. Simpson (Eds.), Commissioning the Past: Understanding South Africa's Truth and Reconciliation Commission (pp. 220-251). Johannesburg: Witwatersrand University Press. 
Sköld, J. (2016). The truth about abuse? A comparative approach to inquiry narratives on historical institutional child abuse. History of Education, 45(4), 492-509.

Sköld, J., \& Swain, S. (2015). Apologies and the Legacy of Abuse of Children in 'care' International Perspectives. London: Palgrave Macmillan.

Smyth, M. (2001). Putting the Past in its Place: Issues of Victimhood and Reconciliation in Northern Ireland's Peace Process. In N. Biggar (Ed.), Burying the Past: Making Peace and Doing Justice after Civil Conflict (pp. 107-130). Washington D.C.: Georgetown University Press.

Snyder, J., \& Vinjamuri, L. (2003). Trials and Errors: Principle and Pragmatism in Strategies of International Justice. International Security, 28(3), 5-44.

Sprenkels, R. (2017). 'Restricted Access': Promises and Pitfalls of Victim Participation in Transitional Justice Mechanisms. A Comparative Perspective. Netherlands: Impunity Watch.

Stover, E. (2004). Witnesses and the promise of justice in The Hague. In E. Stover \& H. Weinstein (Eds.), My neighbor, My Enemy: Justice and Community in the Aftermath of Mass Atrocity (pp. 104-120). New York: Cambridge University Press.

Swain, S., Wright, K., \& Sköld, J. (2018). Conceptualising and Categorising Child Abuse Inquiries: From Damage Control to Foregrounding Survivor Testimony. Journal of Historical Sociology, 31(3), 282-296.

Taylor, D. (2014). Victim Participation in Transitional Justice Mechanisms: Real Power or Empty Ritual? The Netherlands: Impunity Watch.

Terry, K. J. (2015). Child sexual abuse within the Catholic Church: a review of global perspectives. International Journal of Comparative and Applied Criminal Justice, 39(2), 139-154.

UN. (2010). Guidance Note of the Secretary-General: United Nations Approach to Transitional Justice. Geneva \& New York: UN.

UN. (2012). Report of the Special Rapporteur on the promotion of truth, justice, reparation and guarantees of non-recurrence, Pablo de Greiff. A/HRC/21/46. Geneva \& New York: UN.

United Nations OHCHR. (2009). Rule of Law Tools for Post-Conflict States: National Consultations on Transitional Justice, HR/PUB/09/2. Geneva: United Nations Office of the High Commissioner for Human Rights.

United Nations Committee on the Rights of the Child. (2014). Concluding Observations on the Second Periodic Report of the Holy See, 25 February 2014. Retrieved from https://tbinternet.ohchr.org/Treaties/CRC/Shared\%20Documents/VAT/CRC_C_VAT _CO_2_16302_E.pdf. Accessed 1 October 2019.

Wilson, R. (2001). The politics of truth and reconciliation in South Africa : legitimizing the post-apartheid state. Cambridge ; New York: Cambridge University Press.

Wright, K., Sköld, J., \& Swain, S. (2018). Examining abusive pasts: Reassessing institutional violence and care through commissions of inquiry. Traverse Journal of History / Revue d'histoire, 25(3), 149-165.

Wright, K., \& Swain, S. (2018). Speaking the Unspeakable, Naming the Unnameable: The Royal Commission into Institutional Responses to Child Sexual Abuse. Journal of Australian Studies, 42(2), 139-152.

Wright, K., Swain, S., \& McPhillips, K. (2017). The Australian Royal Commission into Institutional Responses to Child Sexual Abuse. Child Abuse \& Neglect, 74, 1-9.

Wright, K., Swain, S., \& Sköld, J. (2017). The Age of Inquiry: A global mapping of institutional abuse inquiries. Retrieved from http://www.lib.latrobe.edu.au/research/ageofinquiry/index.html 